\title{
Advances in the development of antibody-based immunotherapy against prion disease
}

This article was published in the following Dove Press journal:

Antibody Technology Journal

30 August 2014

Number of times this article has been viewed

\section{Huiying Gu' \\ Richard C Dodel ${ }^{2}$ \\ Martin R Farlow' \\ Yansheng Du'}

'Department of Neurology, School of Medicine, Indiana University, Indianapolis, IN, USA; '2Department of Neurology, Philipps University, Marburg, Germany
Correspondence: Yansheng Du

Department of Neurology,

School of Medicine, Indiana University,

975 W Walnut St IB457, Indianapolis,

IN 46202, USA

Tel +I 3172772659

Fax +I 3172776146

Email ydu@iupui.edu
Abstract: Prion disease, also known as transmissible spongiform encephalopathies, is the name given to a group of neurodegenerative disorders. Transformation of the cellular prion protein $\left(\mathrm{PrP}^{\mathrm{C}}\right)$ into self-replicating and proteinase K-resistant $\operatorname{PrP}\left(\mathrm{PrP}^{\mathrm{Sc}}\right)$ in the brain is the pathological hallmark of the disease. All prion disorders have a rapidly progressive and lethal course after onset, and no effective therapy currently exists. Antibody-based immunotherapy has been extensively investigated in neurodegenerative disorders associated with protein misfolding, including prion disease. This review summarizes and outlines the developments in and limitations of active and passive immunization approaches to the prevention and treatment for prion disease. In addition, the potential of these therapeutic strategies is discussed.

Keywords: transmissible spongiform encephalopathies, neurodegenerative, prion protein, proteinase K-resistant PrP

\section{Introduction}

Prion disease, also known as transmissible spongiform encephalopathies, is the name given to a group of rare progressive brain disorders characterized by spongiform degeneration of the central nervous system (CNS) that consists of neuronal death, insoluble prion and amyloid aggregates, astrogliosis, and neuroinflammation. ${ }^{1}$ The crucial event in the pathogenesis of these disorders is the conformational transformation of the cellular prion protein $\left(\mathrm{PrP}^{\mathrm{C}}\right)$ into a self-replicating and proteinase K-resistant conformer, termed "scrapie $\mathrm{PrP} "\left(\mathrm{PrP}^{\mathrm{Sc}}\right) .{ }^{2} \mathrm{PrP}^{\mathrm{Sc}}$ induces the formation of neurotoxic amyloid aggregation deposits in brain tissues, which leads to neuropathological alterations.

Transmissible spongiform encephalopathies caused by altered forms of PrP include scrapie in sheep, bovine spongiform encephalopathy in cattle, as well as the human forms Kuru, Creutzfeldt-Jakob disease, and Gerstmann-Sträussler-Scheinker syndrome. ${ }^{3}$ These diseases are more likely to be caused by refolding and aggregation of the normal $\mathrm{PrP}^{\mathrm{C}}$ into the highly insoluble $\mathrm{PrP}^{\mathrm{Sc}}$. Although $\mathrm{PrP}^{\mathrm{C}}$ and $\mathrm{PrP}^{\mathrm{Sc}}$ have the same amino acid sequence, the $\operatorname{PrP}^{\mathrm{Sc}}$ conformer is enriched in a $\beta$-sheet structure, whereas the normal $\operatorname{PrP}^{\mathrm{C}}$ conformer has little or no $\beta$-sheet and is enriched in an $\alpha$-helix. In this process, a portion of the $\alpha$-helix and random coil structure of $\operatorname{PrP}^{\mathrm{C}}$ changes to the disease-specific $\mathrm{PrP}^{\mathrm{Sc}} \beta$-sheet structure, rendering the protein insoluble and resistant to protease digestion. ${ }^{3}$

In humans, familial Creutzfeldt-Jakob disease, Gerstmann-Sträussler-Scheinker syndrome, and fatal familial insomnia represent the core phenotypes of genetic prion disease. These diseases are known to be caused by mutations in the prion protein gene $(P R N P)$. In addition to familial prion disease, CJD can occur in sporadic and variant 
types through an infection with exogenous prions via contact with blood or lymphoid tissues (such as tonsil and appendix). Although the incubation time for individuals infected with $\mathrm{PrP}^{\mathrm{Sc}}$ is variable, human prion disease has a long incubation period that can last up to 40 years before the onset of clinical signs and symptoms. ${ }^{4}$ Due to this long incubation period, the risk of transmission by asymptomatic carriers becomes a public health issue. ${ }^{5}$ Interestingly, lymphatic organs contain high concentrations of $\mathrm{PrP}^{\mathrm{Sc}}$ long before $\mathrm{PrP}^{\mathrm{Sc}}$ replication starts in the brain ${ }^{6}$ and are more permissive to prions than the brain. ${ }^{7}$

There are no approved treatments available for prion disease. Active and passive immunization has been investigated in prion disease and other neurodegenerative disorders such as Alzheimer's disease (AD) and Parkinson's disease. ${ }^{8}$ Here, we provide an overview of the function of the prion protein and immunization-based therapeutic approaches for prion disease models, and discuss the potential of immunotherapy in human prion disease.

\section{Prion proteins and prion propagation} $\mathrm{PrP}^{\mathrm{C}}$ - a highly conserved $32 \mathrm{kDa}$ glycoprotein with an unstructured N-terminus and a well-structured C-terminus, folded into a series of three $\alpha$-helices and a double-stranded antiparallel $\beta$-sheet - has been identified in marsupials, birds, and almost all vertebrates. ${ }^{9,10} \mathrm{PrP}^{\mathrm{C}}$ is expressed in most tissues and organs including the heart, lungs, and lymphatic system. ${ }^{11,12}$ However, the highest levels of expression are observed in the CNS. ${ }^{13} \operatorname{PrP}^{\mathrm{C}}$ is widely expressed in immune system cells. ${ }^{14}$ The function of PrPc remains unclear even though the physiological role of $\operatorname{PrP}^{\mathrm{C}}$ has been investigated extensively. Mice lacking $\operatorname{PrP}^{\mathrm{C}}$ are resistant to prion disease following inoculation. ${ }^{15}$ They are normal ${ }^{16}$ and have only subtle neurological defects, such as abnormal synaptic transmission and hippocampal morphology, ${ }^{17}$ alterations in circadian rhythm and sleep, ${ }^{18}$ or a reduction in slow afterhyperpolarization. ${ }^{19} \mathrm{PrP}^{\mathrm{C}}$ has a regulatory role in copper metabolism and transport, ${ }^{20}$ which may be involved in prionrelated neurotoxicity. ${ }^{21}$ Some studies indicate that $\operatorname{PrP}^{\mathrm{C}}$ plays a role in neuroprotection. $\mathrm{PrP}^{\mathrm{C}}$ protected cells from oxidative stress $^{22,23}$ and internal or environmental stresses that initiate an apoptotic program (reviewed in Roucou and LeBlanc ${ }^{24}$ and Roucou et $\mathrm{al}^{25}$ ).

It is well known that prion disease consists principally or entirely of an abnormal isoform of a host-encoded protein $\left(\mathrm{PrP}^{\mathrm{C}}\right)$, designated " $\mathrm{PrP} \mathrm{Pc}^{\mathrm{Sc}}{ }^{3}{ }^{3} \mathrm{PrP}$ ' is transformed from $\operatorname{PrP}^{\mathrm{C}}$ by a posttranslational mechanism. ${ }^{26,27}$ However, there are no amino acid sequencing or covalent posttranslational modification differences between $\mathrm{PrP}^{\mathrm{C}}$ and $\mathrm{PrP}^{\mathrm{Sc}} \cdot{ }^{28}$ The feature of prion disease is the deposition and aggregation of misfolded $\mathrm{PrP}^{\mathrm{Sc}}$. The aggregation of $\mathrm{PrP}^{\mathrm{Sc}}$ in affected brain areas is thought to lead to neuronal dysfunction and death, thus producing the clinical symptoms associated with the disease. ${ }^{3,29,30}$ Accumulation of misfolded $\mathrm{PrP}^{\mathrm{Sc}}$ results from an imbalance in the deposition and clearance of aggregates, and the failure of various cellular defense mechanisms. Accordingly, $\mathrm{PrP}^{\mathrm{Sc}}$ represents a primary target for therapeutic strategies. ${ }^{31}$ The expression of $\mathrm{PrP}^{\mathrm{C}}$ is not restricted to the brain but occurs also in peripheral tissues including normal human lymphocytes, monocytes, neutrophils, and lymphoid cells. ${ }^{32-34}$ This indicates that $\mathrm{PrP}^{\mathrm{C}}$ expression is not cell-type specific. In fact, $\operatorname{PrP}^{\mathrm{C}}$ expresses about four times more on activated lymphocyte surfaces than on resting cells, thus providing a potential reservoir of $\mathrm{PrP}^{\mathrm{Sc}}$ replication. ${ }^{32}$ In CJD, which is linked to the codon 200 mutation of the $\operatorname{PrP}$ gene, monocytes and lymphocytes express not only $\mathrm{PrP}^{\mathrm{C}}$ but also altered PrP isoforms. ${ }^{33}$

Studies show that latent-stage prion disease is characterized by the accumulation of $\mathrm{PrP}^{\mathrm{Sc}}$ in lymphatic organs such as the spleen, tonsils, lymph nodes, or gut before its accumulation in the CNS, ${ }^{6,35,36}$ although the degree of involvement is highly variable. ${ }^{37}$ Splenic $\mathrm{PrP}^{\mathrm{Sc}}$ is detectable in at least onethird of patients with sporadic CJD. ${ }^{38}$ The spleen is the site of initial prion accumulation in bovine spongiform encephalopathy. ${ }^{39}$ The mechanism through which prion is transported from the gut to the spleen is unknown, but immune suppression by treatments such as splenectomy or immunosuppressive drugs increases the incubation period. Splenectomized mice have a marked increase in lifespan compared with those which have not had a splenectomy. ${ }^{40}$

"Follicular dendritic cells" (FDCs) are the stromal cells located in the primary B-cell follicles and germinal centers of lymphoid tissues. ${ }^{41}$ FDCs in the spleen express large amounts of $\mathrm{PrP}^{\mathrm{C}}$ and are thought to be involved in $\mathrm{PrP}^{\mathrm{Sc}}$ accumulation and play a role in transepithelial transport of $\mathrm{PrP}^{\mathrm{Sc}}$. After peripheral exposure, prions accumulate first on FDCs, then, from the lymphoid tissues, invade the CNS via the peripheral nervous system. ${ }^{42-44}$ Although prion neuroinvasion from peripheral sites of exposure is dependent on the presence of FDCs in lymphoid tissues, prions are also considered to be acquired by FDCs as complement-opsonized immune complexes. ${ }^{45}$ A number of studies show that FDCs are the main site of prion replication in the spleen, and neuroinvasion is impaired in immunodeficient mice that lack, ${ }^{43,46,47}$ or following the temporary inactivation of, FDCs. ${ }^{48,49}$ Further, FDC depletion in mice before intraperitoneal $\mathrm{PrP}^{\mathrm{Sc}}$ inoculation leads to 
an increased lifespan and almost no prion accumulation in the spleen compared with these in control mice..$^{48,50}$

\section{Immunotherapy for prion disease}

Prion disease is now among the best understood of the degenerative brain diseases, and the development of rational treatments is appearing realistic. Various compounds have been investigated to treat prion disease by influencing the maintenance of prion infection state, such as polyene antibiotics, ${ }^{51}$ anthracycline, ${ }^{52}$ Congo red, ${ }^{53}$ dextran sulfate, pentosan polysulfate and other polyanions, ${ }^{54-56}$ and $\beta$-sheet breaker peptides. ${ }^{57}$ Some of these compounds have effects on prion animal models by delaying the incubation time of animals infected with $\mathrm{PrP}^{\mathrm{Sc}}$, but all have limitations because of toxicity or bioavailability. The basic strategies of active and passive vaccination have been applied to neoplastic, autoimmune, and atherosclerotic diseases. The immunotherapeutic armamentarium has been used to treat AD and other neurodegenerative disorders. Immunization strategies have been effective in the clearance of misfolded proteins in AD. ${ }^{8}$ Beneficial effects have been achieved using active as well as passive immunization against amyloid $\beta(A \beta)$ protein in transgenic mouse models of AD. ${ }^{58-60}$ More than ten human clinical trials evaluating active and passive immunization strategies are currently underway. ${ }^{8}$ The beneficial effect of immunization in AD suggests that this approach may also be feasible for the treatment of prion disease. Previous studies have indicated that immunotherapeutic strategies against the cellular form of $\mathrm{PrP}^{\mathrm{C}}$ can antagonize prion infectivity and disease development due to inoculation with external $\operatorname{PrP}^{\mathrm{Sc}}{ }^{61,62} \mathrm{~A}$ number of studies in tissue culture have shown that anti-PrP antibodies can suppress prion replication. ${ }^{63,64}$ Importantly, transgenic expression or the passive transfer of monoclonal antibodies against PrP into scrapie-infected mice has been found to suppress peripheral prion replication as well as prion infectivity, and significantly delay disease onset. ${ }^{6,65}$ In addition, it has been shown that humoral immune responses to native eukaryotic prion protein correlate with anti-prion protection. ${ }^{66}$

Moreover, because the native prion protein $\left(\operatorname{PrP}^{\mathrm{C}}\right)$ is widely expressed throughout life, $\operatorname{PrP}^{\mathrm{C}}$ and $\mathrm{PrP}^{\mathrm{Sc}}$ have the same amino acid sequence and do not seem to have immunologically distinguishable epitopes. ${ }^{67}$ The key challenge in immunological approaches to prion therapy is to overcome self-immune tolerance. The generation of antibodies against the prion protein is very difficult. ${ }^{68,69}$ It is hard to produce effective active and passive vaccinations in experimental animals. ${ }^{70}$ Several strategies have been used to overcome this barrier, including using genetically engineered mice to produce single-chain anti-PrP antibodies, ${ }^{68}$ infusing prion-specific monoclonal antibodies produced using PrP knockout mice ${ }^{65}$ including immunization with DNA or RNA vectors containing the PRNP gene, ${ }^{71}$ or with various prion peptides, ${ }^{72-74}$ recombinant prion protein, ${ }^{75,76}$ or $\mathrm{PrP}^{\mathrm{Sc}}$ from scrapie-infected mouse brain or neuroblastoma N2a/22L cells $^{75,77}$ and actively vaccinating mice with highly immunogenic papilloma virus-derived particles displaying PrP epitopes. $^{78}$

\section{Active versus passive immunization: advantages and disadvantages}

Active and passive immunotherapies are currently under investigation for prion disease. While both try to delay onset and prolong the lifespan, each has its own advantages and disadvantages. Active vaccination, for example, induces B-cell- and T-cell-mediated immune responses, promoting the production of anti-antigen antibodies. Typically, an active vaccine is comprised of an antigen (alone or conjugated to a non-self T-helper cell epitope) combined with an immune boosting adjuvant to ensure high antibody titers. On the one hand, active immunotherapy is attractive because it can induce long-term antibody production in a large population while being cost-effective, but, on the other, an active vaccine also can increase the risk of a deleterious immune response. A polyclonal antibody response can be induced by an active vaccine, which means that antibodies recognize multiple, sometimes overlapping, epitopes on the target protein. This may be helpful for broad coverage or less useful if the goal is to lower one specific form of a protein but not all forms.

Passive immunotherapy involves the direct injection of antibodies without requiring the immune system to generate an immune response. Benefits of passive immunotherapy are that it can target specific epitopes or pathogenic conformations without disturbing other forms of the protein of interest and can be stopped immediately if there are any adverse reactions. However, passive immunization needs expensive humanized antibodies, so it less feasible than active immunization for the long-term treatment of a large population. In addition, repeated dosing with antibodies over time may form anti-antibodies, which could result in neutralization and/ or have other unwanted immunological side effects such as glomerulonephritis and vasculitis.

\section{Active immunization}

In prion infection in wild-type animals, either natural or experimental, no peripheral humoral immune response 
against PrP epitopes can be observed. ${ }^{79,80}$ The humoral immune response against the disease-specific isoform $\mathrm{PrP}^{\mathrm{Sc}}$ is suppressed either by self-tolerance or by other mechanisms. As already mentioned, the generation of antibodies against the prion protein is very difficult ${ }^{68,69}$ and few studies have used full-length PrP. The first report of an antibody response having been elicited by immunization with full-length $\operatorname{PrP}$ in wild-type mice was published in $2002 .{ }^{81}$ In that study, researchers used the heat shock protein (Hsp), as it exerts an extraordinarily strong adjuvant effect when coupled to an antigen ${ }^{82}$ to elicit antibodies against $P r P$ in mice by injecting a vaccine consisting of PrP cross-linked with DnaK, an Hsp70 homolog of Escherichia coli. Another group used mouse recombinant full-length $\operatorname{PrP}$ and complete Freund adjuvant to immunize CD1 mice. ${ }^{83}$ The onset of prion disease in these mice was delayed and this correlated well with the antibody titer. However, Ishibashi et al repeated this experiment in $\mathrm{BALB} / \mathrm{c}$ mice and failed to delay the onset. ${ }^{84}$ Interestingly, mice immunized with recombinant bovine PrP had a delayed onset compared with non-immunized mice after inoculation with a mouse prion. ${ }^{84}$ Another study showed that PrPDynabeads stimulated the immune system in a murine scrapie model to produce anti-PrP immunoglobulin (Ig) M antibodies and prolonged onset after repeated immunization. ${ }^{85}$

Some research groups have used truncated prion peptides as immunogens for the production of antibodies. However, though many modified truncated prion peptides induce an antibody response in animal models, only a few delay onset and slow progression of the disease. ${ }^{86-88}$ Three mice strains are immunized with different kinds of prion peptides such as $\mathrm{P}_{31-50}, \mathrm{P}_{131-150}, \mathrm{P}_{211-230}$, and $\mathrm{P}_{151-170}$, and some fit the MHC class II peptide binding motif. Strong immune responses are elicited in NOD, C57BL/6, and A/J mice. A reduced level of protease-resistant $\mathrm{PrP}^{\mathrm{Sc}}$ has been observed in mice vaccinated with prion peptide. This demonstrates that self-PrP peptides are immunogenic in mice and suggests that this immune response might affect PrP-scrapie levels in certain conditions ${ }^{89}$ Significantly prolonged disease incubation and survival times have been demonstrated in inoculated wildtype mice, which were subsequently infected by exposure to the scrapie agent with synthetic prion protein-derived peptide $\left(\mathrm{PrP}_{105-125}\right)$ covalently linked to keyhole limpet hemocyanin. ${ }^{90}$ However, immunization with $\operatorname{PrP}_{90-230}$ or adjuvant alone has no effect on disease development. ${ }^{90}$ In a different study, bone-marrow-derived dendritic cells (DCs) loaded with prion peptide were investigated to see whether they could overcome tolerance in PrP-proficient wild-type mice and protect them against scrapie. ${ }^{91}$ Peptide $\left(\mathrm{PrP}_{98-127}\right.$ and $\left.\operatorname{PrP}_{158-187}\right)$-loaded DCs elicited immune responses, including lymphokine release and antibody secretion against native cellular $\operatorname{PrP}^{\mathrm{C}}$. Mice that received $\mathrm{PrP}_{98-127}$-loaded DCs had a reduced infection rate as a result of 139A scrapie intraperitoneal inoculation and significantly increased lifespan. ${ }^{91}$ Recently, another study evaluated the antigenic potential of recombinant murine prion protein in a mouse model of acute depletion of mature FDCs. ${ }^{92}$ The survival time of the FDC-depleted mice was elongated compared with that of the control mice, ${ }^{92}$ suggesting a new strategy in prion treatment.

Because oral infection is the major route of prion transmission for many prionoses, some groups have focused on inducing mucosal immunity. In one study, BALB/c mice were intragastrically or intranasally inoculated with a recombinant PrP-fragment $\left(\mathrm{PrP}_{90-231}\right)$ and cholera toxin (CT) adjuvant. ${ }^{93}$ The vaccine did not prevent disease but elongated the survival time of the animals. Another group has reported that mucosal vaccination with an attenuated Salmonella vaccine strain expressing mouse PrP delayed or prevented prion disease in mice later exposed orally to the 139A scrapie strain. ${ }^{94}$ The gut anti-PrP IgA and systemic anti-PrP IgG were induced by this mucosal vaccine and no toxicity was found with this vaccination approach. ${ }^{94}$ In the researchers' following study, they divided immunized mice into high- and low-titer groups based on mice serum antibody levels. Mice with a high mucosal anti-PrP IgA and a high systemic IgG titer remained without symptoms for 400 days following $\mathrm{PrP}^{\mathrm{Sc}}$ infection. The brains from clinically asymptomatic mice have been found to be $\mathrm{PrP}^{\mathrm{Sc}}$-free. ${ }^{95}$ These findings suggest that effective mucosal vaccination is a feasible and useful method to prevent prion infection via an oral route. Further research is needed to evaluate the effect of mucosal vaccination in preventing prion infection via intraperitoneal and subcutaneous administration.

Though the PrP vaccines show benefit in prion disease, they may cause adverse effects in the immunized host, such as neurotoxicity, ${ }^{96,97}$ autoimmune responses to $\mathrm{PrP}^{\mathrm{C}}$ in the immunized host, and the possible risk of the conversion of $\mathrm{PrP}^{\mathrm{C}}$ into $\mathrm{PrP}^{\mathrm{Sc}}$ or prions. Considering these potential risks, a new type of vaccination against prion disease involving the immunization of mice with antigenic mimicry-mediated anti-prion epitopes is under investigation. One group reports that recombinant mouse PrP mixed with RNAs and lipids is converted into infectious $\mathrm{PrP}^{\mathrm{Sc}} .{ }^{98}$ The result indicates that molecules other than PrP may be used as prion vaccines. Heterologous PrPs function as antigens, mimicking the host's PrP molecules.$^{84}$ Heterologous recombinant bovine and sheep PrPs are highly immunogenic in mice and induced anti-PrP auto-Abs in them. Further, immunization with these proteins significantly prolonged incubation times in mice 
inoculated with the mouse-adapted Fukuoka- 1 prion. ${ }^{84}$ This suggests that antigens mimicking anti-prion epitopes could behave as prion vaccines. Mice immunized with recombinant succinylarginine dihydrolase, a bacterial molecule that carries a sequence similar to the $6 \mathrm{H} 4$ anti-prion epitope, possessed anti-prion activity in sera and had reduced levels of $\mathrm{PrP}^{\mathrm{Sc}}$ in prion-infected cells. ${ }^{99}$ The immunization of the recombinant protein was found to significantly prolong the survival times of mice infected with Fukuoka-1 prions. ${ }^{99}$

"Protein-bound polysaccharide K" (PSK) is a clinical immunotherapeutic agent that exhibits various biological activities. Its anti-prion activity has been reported. A single subcutaneous dose of PSK significantly prolonged the survival time of peritoneally prion-infected mice, suggesting that PSK may be useful in elucidating the mechanism of prion replication. ${ }^{100}$

\section{Passive immunization}

In vitro studies have shown that anti-PrP antibody may inhibit prion infection. ${ }^{63,64,101-105}$ Preincubation with anti-PrP anti-sera reduces the prion titer of infectious microsomes from hamster brain homogenates in vitro. ${ }^{106} \mathrm{PrP}^{\mathrm{Sc}}$ formation is inhibited by an anti-PrP antibody in a cell-free system. ${ }^{107}$ Passive immunization may prevent prion protein replication and offer effective protection against prion disease. Recently, passive immunization has been extensively investigated (Figure 1). ${ }^{63,68,96,108-113}$

Transgenic expression of the $\mu$ heavy chain of anti-PrP antibody $6 \mathrm{H} 4$ in $P R N P^{-/-}$mice was found to completely prevent prion infection after intraperitoneal $\mathrm{PrP}^{\mathrm{Sc}}$ administration. ${ }^{68}$ The most common way of administering anti-prion antibodies to prion-infected mice is peripherally. Intraperitoneal injection of a monoclonal antibody in CD-1 mice once a week has been found to delay the onset of disease after the intraperitoneal administration of $\mathrm{PrP}^{\mathrm{Sc}} \cdot{ }^{108}$ Another study has shown that monoclonal antibody ICSM35 or ICSM18 (4,000 $\mu \mathrm{g} /$ week intraperitoneally) prevents the accumulation of $\mathrm{PrP}^{\mathrm{Sc}}$ in the spleen and delays the onset of disease when administered in the asymptomatic phase. This shows that peripheral prion infection could be prevented if treatment is continued for either 7 or 30 days immediately following PrPsc challenge. ${ }^{65}$ However, no effect was observed after clinical symptoms appeared or in mice injected intracerebrally

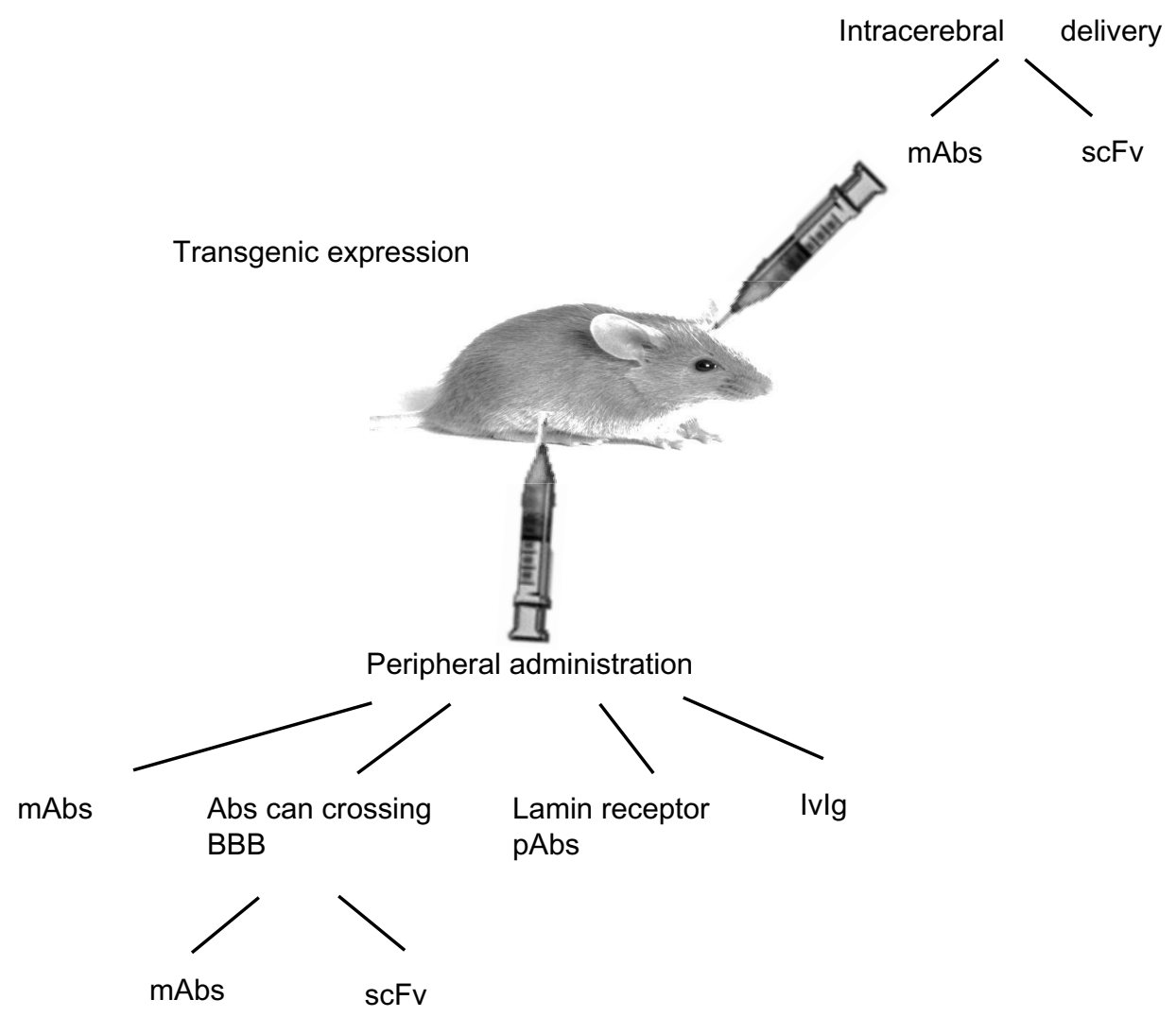

Figure I Methods of administration of anti-prion antibodies to prion-infected mice.

Notes: Passive immunization for prion disease was investigated. Transgenic expression of anti-PrP antibody in PRNP ${ }^{-1-}$ mice has been used to prevent prion infection. Peripheral administration of anti-prion antibodies to prion-infected mice is the most common method. Intracerebral administration was another method to passively immunize mice. Peripheral administration of anti-prion mAbs, anti-prion Abs (mAbs and scFv) that can cross the BBB, lamin receptor pAbs, and Ivlg were investigated to treat prion disease.

Abbreviations: mAbs, monoclonal antibodies; BBB, blood-brain barrier; scFv, single-chain variable fragment; pAbs, polyclonal antibodies; Ivlg, intravenous immunoglobulin; Abs, antibodies. 
with $\mathrm{PrP}^{\mathrm{Sc}}{ }^{65}$ Passive immunization of mice with anti-PrP monoclonal antibody 6D11 (residues 97-100) results in a reduction of splenic levels of $\mathrm{PrP}^{\mathrm{Sc}}$ and prolongs incubation time and survival. ${ }^{114} \mathrm{~A}$ rebound of $\mathrm{PrP}^{\mathrm{Sc}}$ replication appears after cessation of treatment. ${ }^{114}$ An anti-prion protein antibody, mAb31C6, which recognizes amino acids 143-149 of mouse PrP, peripherally administered via the tail veins of prion-infected mice at the time of clinical onset, has been found to decrease the level of $\mathrm{PrP}^{\mathrm{Sc}}$ and elongate survival time in these mice by more than half compared with control mice. ${ }^{115}$ This suggests that the peripheral administration of an anti-PrP antibody is more useful for the prevention of prion disease onset. ${ }^{115}$ Continuous intraperitoneal treatment with anti-PrP antibodies 8B4 (residues 34-52) and 8H4 (175-185) after peripheral prion-disease infection has been found to delay disease development. ${ }^{108}$ Injection of different anti-PrP antibodies has been found to induce a large (up to 100 -fold) increase in circulating $\mathrm{PrP}^{\mathrm{C}}$ and greatly elongate the lifespan of infected animals. ${ }^{116}$ The efficacy of delaying $\mathrm{PrPsc}^{\mathrm{Sc}}$ peripheral accumulation is associated with the monoclonal antibody capacity to form long-lasting complexes with endogenous $\operatorname{PrP}^{\mathrm{C}}$ in the plasma. ${ }^{116}$

Due to relatively large molecules, anti-prion antibodies have poor blood-brain barrier (BBB) permeability. The intracerebral delivery of anti-PrP antibodies could be an alternative or additional approach. The direct intraventricular injection of anti-PrP antibodies using an osmotic pump into PrP-inoculated mice up to 120 days post-inoculation, which is just after clinical onset, has been found to reduce PrPsc levels. ${ }^{117}$ The spongiform changes, microglial activation, and astrogliosis appear milder in anti-PrP monoclonal antibody treated mice than in control mice. Treatment initiated at 60 days was found to elongate the lifespan of the mice. ${ }^{109}$ However, another group has reported that the administration of anti-PrP antibodies into the CNS has strong adverse effects. ${ }^{93}$ In their study, three different purified, endotoxin-free, $\mathrm{PrP}^{\mathrm{C}}$-specific monoclonal antibodies were stereotaxically injected into the right hippocampus of C57BL/10 mice. Two of the three monoclonal antibodies, IgG D13 and IgG P, recognizing epitopes within the 95 to 105 region of $\mathrm{PrP}$, caused extensive neuronal loss throughout the hippocampal region in the mice injected. ${ }^{96}$ But Klöhn et al found no evidence to show that the brain delivery of PrP antibody triggered mouse hippocampal neuron apoptosis. ${ }^{118}$ They stereotaxically injected ICSM18, recognizing PrP epitope 143 to 153; ICSM35, binding 93 to 105; and fully humanized ICSM18 (both IgG1 and G4 isotypes), into the hippocampus of C57BL/10 mice, using IgG P and IgG D13 as positive controls. Apoptotic cell death throughout the hippocampal region was not observed. ${ }^{118}$

To minimize neurotoxicity, anti-PrP ${ }^{\mathrm{C}} \mathrm{scFv}$ antibodies have been investigated. ScFvs have been considered an option for passive immunotherapy in recent years. ${ }^{119}$ ScFvs consist of immunoglobulin heavy $\left(\mathrm{V}_{\mathrm{H}}\right)$ and light $\left(\mathrm{V}_{\mathrm{L}}\right)$ chains linked with a flexible peptide. ${ }^{120}$ The antibody molecule is small and retains antigen-binding specificity. ScFvs can be packaged in small viral vectors such as recombinant adeno-associated virus (AAV) for injection into the CNS. However, a concern with the clinical use of scFv fragments is stability. Novel scFv variants with improved stability can be selected from large randomly mutated phage-displayed libraries with a specific antigen, ${ }^{120-122}$ and phage display has been successfully used in engineering anti-prion antibodies. ${ }^{10,123}$ An scFv version of a PrP-specific full-length antibody $(6 \mathrm{H} 4)$ has been demonstrated therapeutic ${ }^{63,68}$ and to increase $\mathrm{PrP}^{\mathrm{Sc}}$ clearance when secreted from stably transfected and cultured cells. ${ }^{117}$ Serotype 2 of AAV (AAV2) is one of the most commonly used vectors for brain delivery. It has been tested in Phase I/II clinical trials of AD and Parkinson's disease. ${ }^{124-126}$ AAV9 shows greater intracerebral diffusion and transduction efficiency than AAV2. ${ }^{127,128}$ Wuertzer and colleagues administered the single-chain variable fragment antibody D18 (scFvD18) intracerebrally using AAV2 to delay the onset of scrapie in mice intraperitoneally infected with the Rocky Mountain Laboratory (RML) strain. ${ }^{129}$ Moda et al engineered the single-chain variable fragment antibody D18 (scFvD18), specifically recognizing residues 132-156 of PrP, into the AAV9 vector (AAV9-scFvD18). ${ }^{110}$ Mice were then intracerebrally inoculated with this before being intraperitoneally injected with the RML prion strain. The treatment efficiently reduced the accumulation of proteaseresistant $\operatorname{PrP}$ and significantly delayed the onset of disease in mice. Moreover, the treatment was found to be safe. ${ }^{110}$

To treat prion disease efficiently, anti-prion antibodies that can cross the BBB have also been investigated. Jones et al raised a camelid anti-prion antibody, known as PrioV3, capable of crossing the BBB in vitro and in vivo via receptormediated transport that did not display any neurotoxic effects in a scrapie-susceptible neuroblastoma N2a cell line. ${ }^{111}$ Another recombinant single-chain antibody fragment with the cell peptide penetratin ( $\mathrm{scFv}-\mathrm{CPP}$ ) is able to transfer across the BBB. ${ }^{112}$ New anti-PrP monoclonal antibodies with defined $\mathrm{PrP}$ epitopes having a strong affinity of $\mathrm{PrP}^{\mathrm{Sc}}$ are under investigation. ${ }^{130}$

"LRP/LR", a $37 \mathrm{kDa} / 67 \mathrm{kDa}$ laminin receptor, has a key role in cell adhesion. Further, it acts a receptor for $\mathrm{PrP}^{\mathrm{C}}$ 
and $\mathrm{PrP}^{\mathrm{Sc}}$. The receptor represents an alternative target for the therapy of prion disorder and other neurodegenerative diseases. 113 "W3", a polyclonal antibody of LRP/LR, has abolished $\mathrm{PrP}^{\mathrm{Sc}}$ accumulation after incubation in cell-culture experiments. ${ }^{131-133}$ In vivo experiments have also been undertaken in mice. C75BL/6 mice that received W3 1 week before inoculation with $\mathrm{PrP}^{\mathrm{Sc}}$ had a 1.8 -fold increase in survival time compared with serum-treated control mice. ${ }^{134}$ AAV2 vectors encoding recombinant scFvs N3 and S18, which are monoclonal antibodies to LRP/LR, have also been microinjected to treat scrapie-infected mice. ${ }^{135}$ Passive immunotransfer of the scFv S18 has been found to reduce the level of splenic $\mathrm{PrP}^{\mathrm{Sc}}$; however, this has not prolonged incubation and survival times. ${ }^{135}$

An intravenous immunoglobulin (IVIG) containing anti-A $\beta$ autoantibodies or purified autoantibodies against $A \beta$ has been suggested to treat AD. ${ }^{136-140}$ The naturally occurring autoantibodies against $\mathrm{PrP}$ have recently been detected in humans and purified from IVIG by our group. ${ }^{141}$ These autoantibodies have the same effects as reported mouse monoclonal antibodies against PrP fibril formation and PrP neurotoxicity, ${ }^{140,142}$ as well as anti-A $\beta$ antibodies. ${ }^{140,143}$ Autoantibodies with complete human sequences are able to overcome the inflammatory side effects generated by active immunization or humanized monoclonal antibody chronic therapy, particularly when it is found that two humanized antibodies against $\operatorname{PrP}_{95-106}$ might be proapoptotic in the hippocampus. ${ }^{96}$ Interestingly, prion autoantibodies have a high affinity for $\mathrm{PrP}^{\mathrm{Sc}}$ and protect against the neurotoxic effects of $\mathrm{PrPsc}^{\mathrm{Sc}}$ in cell culture. ${ }^{140}$ Autoantibodies enhance the uptake of $\operatorname{PrP}_{106-126}$ A117V in microglial cells without inducing an inflammatory response. ${ }^{144}$ After determining the most effective binding epitopes in prion proteins and purifying the autoantibodies from IVIG by using these epitopes, these autoantibodies could be quickly and effectively used in clinical studies of prion disease to greatly reduce treatment doses and durations. Additionally, the identification of binding sequences from these autoantibodies could further help develop scFv with the complete human sequence for chronic treatments. Studies in these areas are currently underway.

\section{Conclusion}

There is currently no effective treatment for patients with prion disease. Recently, the beneficial effects of active and passive immunization observed in several neurodegenerative disorders have suggested the potential utility of immunization therapies in both the prevention and treatment of prion disease. The demonstration of complete prevention of prion disease in a mouse model of prion disease by using oral inoculation with $\mathrm{PrP}^{\mathrm{C}}$ expressed in an attenuated Salmonella vector is a major advance in this field. ${ }^{83}$ However, since the use of active immunization strategies for the treatment of human prion disease could potentially result in severe adverse effects such as autoimmune meningoencephalitis, ${ }^{84}$ currently, most researchers favor passive immunization approaches for these chronic diseases. Unfortunately, it should be noted that none of the passive immunization strategies that have been tested in mice has shown beneficial effects on survival when animals were treated with antibodies toward the end of the disease incubation period or after prion accumulation had already occurred in the CNS and clinical signs developed. Passive immunization seems to be preventive by prolonging the incubation period when administered before, or very shortly after, exposure to $\mathrm{PrP}^{\mathrm{Sc}}$. Therefore, methods for the early diagnosis of prion disease are urgently needed. Additionally, passive immunization could be potentially used in patients at risk of $\mathrm{PrP}^{\mathrm{Sc}}$ exposure and in carriers of mutations in the $\operatorname{Pr} P$ gene. Further preclinical and clinical studies are needed to evaluate immunotherapeutic approaches to the prevention and treatment of the devastating effects of human prion disease.

\section{Disclosure}

The authors declare no conflicts of interest in this work.

\section{References}

1. Prusiner SB. The prion diseases. Brain Pathol. 1998;8(3):499-513.

2. McKinley MP, Bolton DC, Prusiner SB. A protease-resistant protein is a structural component of the scrapie prion. Cell. 1983;35(1): $57-62$.

3. Prusiner SB. Molecular biology of prion diseases. Science. 1991; 252(5012):1515-1522.

4. Collinge J. Prion diseases of humans and animals: their causes and molecular basis. Annu Rev Neurosci. 2001;24:519-550.

5. Brown P. Creutzfeldt-Jakob disease: reflections on the risk from blood product therapy. Haemophilia. 2007;13 Suppl 5:33-40.

6. Wisniewski T, Sigurdsson EM. Therapeutic approaches for prion and Alzheimer's diseases. FEBS J. 2007;274(15):3784-3798.

7. Béringue V, Herzog L, Jaumain E, et al. Facilitated cross-species transmission of prions in extraneural tissue. Science. 2012;335(6067): 472-475.

8. Brody DL, Holtzman DM. Active and passive immunotherapy for neurodegenerative disorders. Annu Rev Neurosci. 2008;31:175-193.

9. Windl O, Dempster M, Estibeiro P, Lathe R. A candidate marsupial PrP gene reveals two domains conserved in mammalian PrP proteins. Gene. 1995;159(2):181-186.

10. Harris DA, Lele P, Snider WD. Localization of the mRNA for a chicken prion protein by in situ hybridization. Proc Natl Acad Sci U S A. 1993;90(9):4309-4313.

11. Oesch B, Westaway D, Wälchli M, et al. A cellular gene encodes scrapie PrP 27-30 protein. Cell. 1985;40(4):735-746.

12. Harris DA. Cellular biology of prion diseases. Clin Microbiol Rev. 1999;12(3):429-444. 
13. Kretzschmar HA, Prusiner SB, Stowring LE, DeArmond SJ. Scrapie prion proteins are synthesized in neurons. Am J Pathol. 1986; 122(1): $1-5$.

14. Dodelet VC, Cashman NR. Prion protein expression in human leukocyte differentiation. Blood. 1998;91(5):1556-1561.

15. Büeler H, Aguzzi A, Sailer A, et al. Mice devoid of PrP are resistant to scrapie. Cell. 1993;73(7):1339-1347.

16. Büeler H, Fischer M, Lang Y, et al. Normal development and behaviour of mice lacking the neuronal cell-surface PrP protein. Nature. 1992;356(6370):577-582.

17. Colling SB, Khana M, Collinge J, Jefferys JG. Mossy fibre reorganization in the hippocampus of prion protein null mice. Brain Res. 1997;755(1):28-35.

18. Tobler I, Gaus SE, Deboer T, et al. Altered circadian activity rhythms and sleep in mice devoid of prion protein. Nature. 1996;380(6575): 639-642.

19. Herms JW, Tings T, Dunker S, Kretzschmar HA. Prion protein affects $\mathrm{Ca} 2+$-activated $\mathrm{K}+$ currents in cerebellar purkinje cells. Neurobiol Dis. 2001;8(2):324-330.

20. Stöckel J, Safar J, Wallace AC, Cohen FE, Prusiner SB. Prion protein selectively binds copper(II) ions. Biochemistry. 1998;37(20): 7185-7193.

21. Brown DR, Mohn CM. Astrocytic glutamate uptake and prion protein expression. Glia. 1999;25(3):282-292.

22. Milhavet O, Lehmann S. Oxidative stress and the prion protein in transmissible spongiform encephalopathies. Brain Res Brain Res Rev. 2002;38(3):328-339.

23. Brown DR, Schulz-Schaeffer WJ, Schmidt B, Kretzschmar HA. Prion protein-deficient cells show altered response to oxidative stress due to decreased SOD-1 activity. Exp Neurol. 1997;146(1):104-112.

24. Roucou X, LeBlanc AC. Cellular prion protein neuroprotective function: implications in prion diseases. J Mol Med (Berl). 2005;83(1):3-11.

25. Roucou X, Gains M, LeBlanc AC. Neuroprotective functions of prion protein. J Neurosci Res. 2004;75(2):153-161.

26. Borchelt DR, Scott M, Taraboulos A, Stahl N, Prusiner SB. Scrapie and cellular prion proteins differ in their kinetics of synthesis and topology in cultured cells. J Cell Biol. 1990;110(3):743-752.

27. Caughey B, Raymond GJ. The scrapie-associated form of PrP is made from a cell surface precursor that is both protease- and phospholipasesensitive. J Biol Chem. 1991;266(27):18217-18223.

28. Stahl N, Baldwin MA, Teplow DB, et al. Structural studies of the scrapie prion protein using mass spectrometry and amino acid sequencing. Biochemistry. 1993;32(8):1991-2002.

29. Bugiani O, Giaccone G, Piccardo P, Morbin M, Tagliavini F, Ghetti B. Neuropathology of Gerstmann-Straussler-Scheinker disease. Microsc Res Tech. 2000;50(1):10-15.

30. Ghetti B1, Piccardo P, Frangione B, et al. Prion protein amyloidosis. Brain Pathol. 1996;6(2):127-145.

31. Aguzzi A, Heikenwalder M. Pathogenesis of prion diseases: current status and future outlook. Nat Rev Microbiol. 2006;4(10): $765-775$.

32. Cashman NR, Loertscher R, Nalbantoglu J, et al. Cellular isoform of the scrapie agent protein participates in lymphocyte activation. Cell. 1990;61(1):185-192.

33. Meiner Z, Halimi M, Polakiewicz RD, Prusiner SB, Gabizon R. Presence of prion protein in peripheral tissues of Libyan Jews with CreutzfeldtJakob disease. Neurology. 1992;42(7):1355-1360.

34. Bessos H, Drummond O, Prowse C, Turner M, MacGregor I. The release of prion protein from platelets during storage of apheresis platelets. Transfusion. 2001;41(1):61-66.

35. Heppner FL, Christ AD, Klein MA, et al. Transepithelial prion transport by M cells. Nat Med. 2001;7(9):976-977.

36. Aguzzi A, Sigurdson CJ. Antiprion immunotherapy: to suppress or to stimulate? Nat Rev Immunol. 2004;4(9):725-736.

37. Heikenwalder M, Prinz M, Heppner FL, Aguzzi A. Current concepts and controversies in prion immunopathology. $J$ Mol Neurosci. 2004;23(1-2):3-12.
38. Glatzel M, Abela E, Maissen M, Aguzzi A. Extraneural pathologic prion protein in sporadic Creutzfeldt-Jakob disease. $N$ Engl J Med. 2003;349(19):1812-1820.

39. Daude N. Prion diseases and the spleen. Viral Immunol. 2004;17(3): 334-349.

40. Kimberlin RH, Walker CA. The role of the spleen in the neuroinvasion of scrapie in mice. Virus Res. 1989;12(3):201-211.

41. Park CS, Choi YS. How do follicular dendritic cells interact intimately with B cells in the germinal centre? Immunology. 2005;114(1):2-10.

42. Beekes M, McBride PA. The spread of prions through the body in naturally acquired transmissible spongiform encephalopathies. FEBSJ. 2007;274(3):588-605.

43. Glaysher BR, Mabbott NA. Role of the GALT in scrapie agent neuroinvasion from the intestine. J Immunol. 2007;178(6):3757-3766.

44. Sigurdson CJ, Williams ES, Miller MW, Spraker TR, O’Rourke KI, Hoover EA. Oral transmission and early lymphoid tropism of chronic wasting disease PrPres in mule deer fawns (Odocoileus hemionus). $J$ Gen Virol. 1999;80(Pt 10):2757-2764.

45. Klein MA, Kaeser PS, Schwarz P, et al. Complement facilitates early prion pathogenesis. Nat Med. 2001;7(4):488-492.

46. Mabbott NA, Williams A, Farquhar CF, Pasparakis M, Kollias G, Bruce ME. Tumor necrosis factor alpha-deficient, but not interleukin6-deficient, mice resist peripheral infection with scrapie. $J$ Virol. 2000;74(7):3338-3344.

47. Prinz M, Montrasio F, Klein MA, et al. Lymph nodal prion replication and neuroinvasion in mice devoid of follicular dendritic cells. Proc Natl Acad Sci U S A. 2002;99(2):919-924.

48. Montrasio F, Frigg R, Glatzel M, et al. Impaired prion replication in spleens of mice lacking functional follicular dendritic cells. Science. 2000;288(5469):1257-1259.

49. Mabbott NA, Mackay F, Minns F, Bruce ME. Temporary inactivation of follicular dendritic cells delays neuroinvasion of scrapie. Nat Med. 2000;6(7):719-720.

50. Mabbott NA, Bruce ME, Botto M, Walport MJ, Pepys MB. Temporary depletion of complement component $\mathrm{C} 3$ or genetic deficiency of C1q significantly delays onset of scrapie. Nat Med. 2001;7(4):485-487.

51. Pocchiari M, Schmittinger S, Masullo C. Amphotericin B delays the incubation period of scrapie in intracerebrally inoculated hamsters. J Gen Virol. 1987;68(Pt 1):219-223.

52. Tagliavini F, McArthur RA, Canciani B, et al. Effectiveness of anthracycline against experimental prion disease in Syrian hamsters. Science. 1997;276(5315):1119-1122.

53. Ingrosso L, Ladogana A, Pocchiari M. Congo red prolongs the incubation period in scrapie-infected hamsters. J Virol. 1995;69(1): 506-508.

54. Ehlers B, Diringer H. Dextran sulphate 500 delays and prevents mouse scrapie by impairment of agent replication in spleen. J Gen Virol. 1984;65(Pt 8):1325-1330.

55. Farquhar CF, Dickinson AG. Prolongation of scrapie incubation period by an injection of dextran sulphate 500 within the month before or after infection. J Gen Virol. 1986;67(Pt 3):463-473.

56. Kimberlin RH, Walker CA. Suppression of scrapie infection in mice by heteropolyanion 23, dextran sulfate, and some other polyanions. Antimicrob Agents Chemother. 1986;30(3):409-413.

57. Soto C, Kascsak RJ, Saborío GP, et al. Reversion of prion protein conformational changes by synthetic beta-sheet breaker peptides. Lancet. 2000;355(9199):192-197.

58. Schenk D, Barbour R, Dunn W, et al. Immunization with amyloid-beta attenuates Alzheimer-disease-like pathology in the PDAPP mouse. Nature. 1999;400(6740):173-177.

59. Bard F, Cannon C, Barbour R, et al. Peripherally administered antibodies against amyloid beta-peptide enter the central nervous system and reduce pathology in a mouse model of Alzheimer disease. Nat Med. 2000;6(8):916-919.

60. Morgan D, Diamond DM, Gottschall PE, et al. A beta peptide vaccination prevents memory loss in an animal model of Alzheimer's disease. Nature. 2000;408(6815):982-985. 
61. Hu W, Rosenberg RN, Stuve O. Prion proteins: a biological role beyond prion diseases. Acta Neurol Scand. 2007;116(2):75-82.

62. Korth C, Peters PJ. Emerging pharmacotherapies for Creutzfeldt-Jakob disease. Arch Neurol. 2006;63(4):497-501.

63. Enari M, Flechsig E, Weissmann C. Scrapie prion protein accumulation by scrapie-infected neuroblastoma cells abrogated by exposure to a prion protein antibody. Proc Natl Acad Sci U S A. 2001;98(16): 9295-9299.

64. Peretz D, Williamson RA, Kaneko K, et al. Antibodies inhibit prion propagation and clear cell cultures of prion infectivity. Nature. 2001;412(6848):739-743.

65. White AR, Enever P, Tayebi M, et al. Monoclonal antibodies inhibit prion replication and delay the development of prion disease. Nature. 2003;422(6927):80-83.

66. Polymenidou M, Heppner FL, Pellicioli EC, et al. Humoral immune response to native eukaryotic prion protein correlates with antiprion protection. Proc Natl Acad Sci U S A. 2004;101 Suppl 2: 14670-14676.

67. Aucouturier P, Carnaud C. The immune system and prion diseases: a relationship of complicity and blindness. J Leukoc Biol. 2002;72(6): 1075-1083.

68. Heppner FL, et al. Prevention of scrapie pathogenesis by transgenic expression of anti-prion protein antibodies. Science. 2001;294(5540): 178-182.

69. Korth C, Streit P, Oesch B. Monoclonal antibodies specific for the native, disease-associated isoform of the prion protein. Methods Enzymol. 1999;309:106-122.

70. Bade S, Frey A. Potential of active and passive immunizations for the prevention and therapy of transmissible spongiform encephalopathies. Expert Rev Vaccines. 2007;6(2):153-168.

71. Krasemann S, Groschup MH, Harmeyer S, Hunsmann G, Bodemer W. Generation of monoclonal antibodies against human prion proteins in PrP0/0 mice. Mol Med. 1996;2(6):725-734.

72. Demart S, Fournier JG, Creminon C, et al. New insight into abnormal prion protein using monoclonal antibodies. Biochem Biophys Res Commun. 1999;265(3):652-657.

73. Gregoire S, Logre C, Metharom P, et al. Identification of two immunogenic domains of the prion protein - PrP - which activate class II-restricted $\mathrm{T}$ cells and elicit antibody responses against the native molecule. J Leukoc Biol. 2004;76(1):125-134.

74. Bainbridge J, Walker B. Cell mediated immune responses against human prion protein. Clin Exp Immunol. 2003;133(3):310-317.

75. Kim CL, Umetani A, Matsui T, Ishiguro N, Shinagawa M, Horiuchi M Antigenic characterization of an abnormal isoform of prion protein using a new diverse panel of monoclonal antibodies. Virology. 2004;320(1): 40-51.

76. Khalili-Shirazi A, Quaratino S, Londei M, et al. Protein conformation significantly influences immune responses to prion protein. $J$ Immunol. 2005;174(6):3256-3263.

77. Nakamura N, Miyamoto K, Shimokawa M, et al. Generation of antibodies against prion protein by scrapie-infected cell immunization of $\operatorname{PrP}(0 / 0)$ mice. Hybrid Hybridomics. 2003;22(4):263-266.

78. Handisurya A, Gilch S, Winter D, et al. Vaccination with prion peptide-displaying papillomavirus-like particles induces autoantibodies to normal prion protein that interfere with pathologic prion protein production in infected cells. FEBS J. 2007;274(7):1747-1758.

79. Barry RA, McKinley MP, Bendheim PE, Lewis GK, DeArmond SJ, Prusiner SB. Antibodies to the scrapie protein decorate prion rods J Immunol. 1985;135(1):603-613.

80. Bockman JM, Kingsbury DT. Immunological analysis of host and agent effects on Creutzfeldt-Jakob disease and scrapie prion proteins. JVirol. 1988;62(9):3120-3127.

81. Koller MF, Grau T, Christen P. Induction of antibodies against murine full-length prion protein in wild-type mice. J Neuroimmunol. 2002;132(1-2):113-116.

82. Del Giudice G. Hsp70: a carrier molecule with built-in adjuvanticity. Experientia. 1994;50(11-12):1061-1066.
83. Sigurdsson EM, Brown DR, Daniels M, et al. Immunization delays the onset of prion disease in mice. Am J Pathol. 2002;161(1): 13-17.

84. Ishibashi D, Yamanaka H, Yamaguchi N, et al. Immunization with recombinant bovine but not mouse prion protein delays the onset of disease in mice inoculated with a mouse-adapted prion. Vaccine. 2007;25(6):985-992.

85. Tayebi M, Collinge J, Hawke S. Unswitched immunoglobulin M response prolongs mouse survival in prion disease. J Gen Virol. 2009;90(Pt 3):777-782.

86. RoettgerY, Du Y, Bacher M, Zerr I, Dodel R, Bach JP. Immunotherapy in prion disease. Nat Rev Neurol. 2013;9(2):98-105.

87. Arbel M, Lavie V, Solomon B. Generation of antibodies against prion protein in wild-type mice via helix 1 peptide immunization J Neuroimmunol. 2003;144(1-2):38-45.

88. Bainbridge J, Jones N, Walker B. Multiple antigenic peptides facilitate generation of anti-prion antibodies. Clin Exp Immunol. 2004;137(2): 298-304.

89. Souan L, Tal Y, Felling Y, Cohen IR, Taraboulos A, Mor F. Modulation of proteinase- $\mathrm{K}$ resistant prion protein by prion peptide immunization. Eur J Immunol. 2001;31(8):2338-2346.

90. Schwarz A, Krätke O, Burwinkel M, et al. Immunisation with a synthetic prion protein-derived peptide prolongs survival times of mice orally exposed to the scrapie agent. Neurosci Lett. 2003;350(3): 187-189.

91. Bachy V, Ballerini C, Gourdain P, et al. Mouse vaccination with dendritic cells loaded with prion protein peptides overcomes tolerance and delays scrapie. J Gen Virol. 2010;91(Pt 3):809-820.

92. Xanthopoulos K, Lagoudaki R, Kontana A, et al. Immunization with recombinant prion protein leads to partial protection in a murine model of TSEs through a novel mechanism. PLoS One. 2013;8(3): e59143.

93. Bade S, Baier M, Boetel T, Frey A. Intranasal immunization of Balb/c mice against prion protein attenuates orally acquired transmissible spongiform encephalopathy. Vaccine. 2006;24(9):1242-1253.

94. Goñi F, Knudsen E, Schreiber F, et al. Mucosal vaccination delays or prevents prion infection via an oral route. Neuroscience. 2005;133(2): 413-421.

95. Goñi F, Prelli F, Schreiber F, et al. High titers of mucosal and systemic anti-PrP antibodies abrogate oral prion infection in mucosal-vaccinated mice. Neuroscience. 2008;153(3):679-686.

96. Solforosi L, Criado JR, McGavern DB, et al. Cross-linking cellular prion protein triggers neuronal apoptosis in vivo. Science. 2004; 303(5663):1514-1516

97. Lefebvre-Roque M, Kremmer E, Gilch S, et al. Toxic effects of intracerebral PrP antibody administration during the course of BSE infection in mice. Prion. 2007;1(3):198-206.

98. Wang F, Wang X, Yuan CG, Ma J. Generating a prion with bacterially expressed recombinant prion protein. Science. 2010;327(5969): 1132-1135.

99. Ishibashi D, Yamanaka H, Mori T, et al. Antigenic mimicry-mediated anti-prion effects induced by bacterial enzyme succinylarginine dihydrolase in mice. Vaccine. 2011;29(50):9321-9328.

100. Hamanaka T, Sakasegawa Y, Ohmoto A, Kimura T, Ando T, Doh-ura K. Anti-prion activity of protein-bound polysaccharide K in prion-infected cells and animals. Biochem Biophys Res Commun. 2011;405(2):285-290.

101. Beringue V, Vilette D, Mallinson G, et al. PrPSc binding antibodies are potent inhibitors of prion replication in cell lines. $J$ Biol Chem. 2004;279(38):39671-39676.

102. Cardinale A, Filesi I, Vetrugno V, Pocchiari M, Sy MS, Biocca S Trapping prion protein in the endoplasmic reticulum impairs PrPC maturation and prevents PrPSc accumulation. J Biol Chem. 2005;280(1):685-694.

103. Féraudet C, Morel N, Simon S, et al. Screening of 145 anti-PrP monoclonal antibodies for their capacity to inhibit PrPSc replication in infected cells. J Biol Chem. 2005;280(12):11247-11258. 
104. Kim CL, Karino A, Ishiguro N, Shinagawa M, Sato M, Horiuchi M. Cell-surface retention of PrPC by anti-PrP antibody prevents proteaseresistant PrP formation. J Gen Virol. 2004;85(Pt 11):3473-3482.

105. Perrier V, Solassol J, Crozet C, et al. Anti-PrP antibodies block PrPSc replication in prion-infected cell cultures by accelerating PrPC degradation. J Neurochem. 2004;89(2):454-463.

106. Gabizon R, McKinley MP, Groth D, Prusiner SB. Immunoaffinity purification and neutralization of scrapie prion infectivity. Proc Natl Acad Sci U S A. 1988;85(18):6617-6621.

107. Horiuchi M, Caughey B. Specific binding of normal prion protein to the scrapie form via a localized domain initiates its conversion to the protease-resistant state. EMBO J. 1999;18(12):3193-3203.

108. Sigurdsson EM, Sy MS, Li R, et al. Anti-prion antibodies for prophylaxis following prion exposure in mice. Neurosci Lett. 2003;336(3): $185-187$.

109. Song CH, Furuoka H, Kim CL, et al. Effect of intraventricular infusion of anti-prion protein monoclonal antibodies on disease progression in prion-infected mice. J Gen Virol. 2008;89(Pt 6):1533-1544.

110. Moda F, Vimercati C, Campagnani I, et al. Brain delivery of AAV9 expressing an anti-PrP monovalent antibody delays prion disease in mice. Prion. 2012;6(4):383-390.

111. Jones DR, Taylor WA, Bate C, David M, Tayebi M. A camelid anti-PrP antibody abrogates $\mathrm{PrP}$ replication in prion-permissive neuroblastoma cell lines. PLoS One. 2010;5(3):e9804.

112. Skrlj N, Drevenšek G, Hudoklin S, Romih R, Curin Šerbec V, Dolinar M. Recombinant single-chain antibody with the Trojan peptide penetratin positioned in the linker region enables cargo transfer across the bloodbrain barrier. Appl Biochem Biotechnol. 2013;169(1):159-169.

113. Vana K, Zuber C, Pflanz H, et al. LRP/LR as an alternative promising target in therapy of prion diseases, Alzheimer's disease and cancer. Infect Disord Drug Targets. 2009;9(1):69-80.

114. Sadowski MJ, Pankiewicz J, Prelli F, et al. Anti-PrP Mab 6D11 suppresses $\operatorname{Pr} \mathrm{P}(\mathrm{Sc})$ replication in prion infected myeloid precursor line FDC-P1/22L and in the lymphoreticular system in vivo. Neurobiol Dis. 2009;34(2):267-278.

115. Ohsawa N, Song CH, Suzuki A, Furuoka H, Hasebe R, Horiuchi M. Therapeutic effect of peripheral administration of an anti-prion protein antibody on mice infected with prions. Microbiol Immunol. 2013;57(4):288-297.

116. Féraudet-Tarisse C, Andréoletti O, Morel N, et al. Immunotherapeutic effect of anti-PrP monoclonal antibodies in transmissible spongiform encephalopathy mouse models: pharmacokinetic and pharmacodynamic analysis. J Gen Virol. 2010;91(Pt 6):1635-1645.

117. Donofrio G, Heppner FL, Polymenidou M, Musahl C, Aguzzi A. Paracrine inhibition of prion propagation by anti-PrP single-chain $\mathrm{Fv}$ miniantibodies. J Virol. 2005;79(13):8330-8338.

118. Klöhn PC, Farmer M, Linehan JM, et al. PrP antibodies do not trigger mouse hippocampal neuron apoptosis. Science. 2012;335(6064):52.

119. Ahmad ZA, Yeap SK, Ali AM, Ho WY, Alitheen NB, Hamid M. scFv antibody: principles and clinical application. Clin Dev Immunol. 2012;2012:980250.

120. Malone J, Sullivan MA. Analysis of antibody selection by phage display utilizing anti-phenobarbital antibodies. J Mol Recognit. 1996;9(5-6):738-745.

121. Vaughan TJ, Williams AJ, Pritchard K, et al. Human antibodies with sub-nanomolar affinities isolated from a large non-immunized phage display library. Nat Biotechnol. 1996;14(3):309-314.

122. Brockmann EC. Selection of stable scFv antibodies by phage display. Methods Mol Biol. 2012;907:123-144.

123. Flego M, Ascione A, Zamboni S, Dupuis ML, Imperiale V, Cianfriglia M. Generation of human scFvs antibodies recognizing a prion protein epitope expressed on the surface of human lymphoblastoid cells. BMC Biotechnol. 2007;7:38.

124. Kaplitt MG, Feigin A, Tang C, et al. Safety and tolerability of gene therapy with an adeno-associated virus (AAV) borne GAD gene for Parkinson's disease: an open label, phase I trial. Lancet. 2007;369(9579):2097-2105.
125. Marks WJ Jr, Bartus RT, Siffert J, et al. Gene delivery of AAV2neurturin for Parkinson's disease: a double-blind, randomised, controlled trial. Lancet Neurol. 2010;9(12):1164-1172.

126. Mandel RJ. CERE-110, an adeno-associated virus-based gene delivery vector expressing human nerve growth factor for the treatment of Alzheimer's disease. Curr Opin Mol Ther. 2010;12(2):240-247.

127. Burger C, Nash K, Mandel RJ. Recombinant adeno-associated viral vectors in the nervous system. Hum Gene Ther. 2005;16(7): 781-791.

128. Mandel RJ, Manfredsson FP, Foust KD, et al. Recombinant adenoassociated viral vectors as therapeutic agents to treat neurological disorders. Mol Ther. 2006;13(3):463-483.

129. Wuertzer CA, Sullivan MA, Qiu X, Federoff HJ. CNS delivery of vectored prion-specific single-chain antibodies delays disease onset. Mol Ther. 2008;16(3):481-486.

130. Stanker LH, Scotcher MC, Lin A, McGarvey J, Prusiner SB, Hnasko R. Novel epitopes identified by anti-PrP monoclonal antibodies produced following immunization of Prnp $0 / 0 \mathrm{Balb} / \mathrm{cJ}$ mice with purified scrapie prions. Hybridoma (Larchmt). 2012;31(5):314-324.

131. Gauczynski S, Nikles D, El-Gogo S, et al. The 37-kDa/67-kDa laminin receptor acts as a receptor for infectious prions and is inhibited by polysulfated glycanes. J Infect Dis. 2006;194(5):702-709.

132. Gauczynski S, Peyrin JM, Haik S, et al. The 37-kDa/67-kDa laminin receptor acts as the cell-surface receptor for the cellular prion protein. EMBO J. 2001;20(21):5863-5875.

133. Leucht C, Simoneau S, Rey C, et al. The $37 \mathrm{kDa} / 67 \mathrm{kDa}$ laminin receptor is required for $\operatorname{PrP}(\mathrm{Sc})$ propagation in scrapie-infected neuronal cells. EMBO Rep. 2003;4(3):290-295.

134. Zuber C, Mitteregger G, Pace C, Zerr I, Kretzschmar HA, Weiss S. Anti-LRP/LR antibody W3 hampers peripheral PrPSc propagation in scrapie infected mice. Prion. 2007;1(3):207-212.

135. Zuber C, Knackmuss S, Rey C, et al. Single chain Fv antibodies directed against the $37 \mathrm{kDa} / 67 \mathrm{kDa}$ laminin receptor as therapeutic tools in prion diseases. Mol Immunol. 2008;45(1):144-151.

136. DuY, Dodel R, Hampel H, et al. Reduced levels of amyloid beta-peptide antibody in Alzheimer disease. Neurology. 2001;57(5):801-805.

137. Weksler ME, Relkin N, Turkenich R, LaRusse S, Zhou L, Szabo P. Patients with Alzheimer disease have lower levels of serum antiamyloid peptide antibodies than healthy elderly individuals. Exp Gerontol. 2002;37(7):943-948.

138. Dodel R, Hampel H, Depboylu C, et al. Human antibodies against amyloid beta peptide: a potential treatment for Alzheimer's disease. Ann Neurol. 2002;52(2):253-256.

139. Dodel RC, Du Y, Depboylu C, et al. Intravenous immunoglobulins containing antibodies against beta-amyloid for the treatment of Alzheimer's disease. J Neurol Neurosurg Psychiatry. 2004;75(10):1472-1474.

140. Du Y, Wei X, Dodel R, et al. Human anti-beta-amyloid antibodies block beta-amyloid fibril formation and prevent beta-amyloid-induced neurotoxicity. Brain. 2003;126(Pt 9):1935-1939.

141. Wei X, Roettger Y, Tan B, et al. Human anti-prion antibodies block prion peptide fibril formation and neurotoxicity. J Biol Chem. 2012;287(16):12858-12866.

142. Dorban G, Defaweux V, Heinen E, Antoine N. Spreading of prions from the immune to the peripheral nervous system: a potential implication of dendritic cells. Histochem Cell Biol. 2010;133(5):493-504.

143. Dodel R, Balakrishnan K, Keyvani K, et al. Naturally occurring autoantibodies against beta-amyloid: investigating their role in transgenic animal and in vitro models of Alzheimer's disease. J Neurosci. 2011;31(15):5847-5854.

144. Roettger Y, Zerr I, Dodel R, Bach JP. Prion peptide uptake in microglial cells - the effect of naturally occurring autoantibodies against prion protein. PLoS One. 2013;8(6):e67743.

145. Miyake K, Shimada T. Development and Application of HIV Vectors Pseudotyped with HIV Envelopes. In: Ke Xu, editor. Viral Gene Therapy. 2011. Available from: http:/www.intechopen.com/books/ viral-gene-therapy/development-and-application-of-hiv-vectorspseudotyped-with-hiv-envelopes. Accessed July 22, 2014. 
Antibody Technology Journal

\section{Publish your work in this journal}

Antibody Technology Journal is international, peer-reviewed, open access journal publishing original research, reports, reviews and commentaries on all areas of antibody technology. The manuscript management system is completely online and includes a very quick and fair

peer-review system. Visit http://www.dovepress.com/testimonials.php to read real quotes from published authors. 